\title{
Sosialisasi Pemanfaatan Limbah Biomassa Sebagai Bahan Pembuat Briket
}

\author{
Guyup Mahardhian Dwi Putra*, Diah Ajeng Setiawati, Asih Priyati, Sirajuddin Haji Abdullah \\ Program Studi Teknik Pertanian,Fakultas Teknologi Pangan dan Agroindustri \\ Universitas Mataram, INDONESIA;
}

\begin{abstract}
Article history
Received: 25 Maret 2019

Revised: 13 Mei 2019

Accepted: 13 Mei 2019

*Corresponding Author: Guyup Mahardhian Dwi Putra

Program Studi Teknik Pertanian,Fakultas Teknologi

Pangan dan Agroindustri

Universitas Mataram, Indonesia

Email*:guyupmdp@unram.ac.id
\end{abstract}

\begin{abstract}
Garbage seems like an unfinished problem in Indonesia, including in Mataram, West Nusa Tenggara. This study aims to reduce organic waste by change it into briquette products that provide benefits value. The method used was distribution of questionnaires, discussions, and practices on how to process organic waste. After this activity, the people become more understands how to treat organic waste and able to use the waste as briquettes.
\end{abstract}

Keywords: Mataram; organic waste; briquette

Abtrak: Sampah menjadi persoalan yang seakan tidak ada habisnya di Indonesia termasuk di Mataram Nusa Tengara Barat. Kegiatan ini bertujuan untuk mengurangi sampah, khususnya sampah organic, menjadi produk briket yang memberikan nilai manfaat. Metode yang digunakan adalah pembagian angket, diskusi, dan praktek cara pengolahan sampah organik. Setelah dilaksanakannya kegiatan ini masyarakat lebih memahami cara mengolah limbah organik dan mampu memanfaatkannya menjadi briket.

Kata Kunci: Mataram; limbah organik; briket

\section{PENDAHULUAN}

Berdasarkan Data Dinas Lingkungan Hidup Kota Mataram (2018), rata-rata volume sampah per hari di Kota Mataram pada tahun 2013 sebanyak $1306 \mathrm{~m}^{3}$, tahun 2014 sebesar $1350 \mathrm{~m}^{3}$, dan tahun 2016 sebesar $1444 \mathrm{~m}^{3}$. Peningkatan sampah ini disebabkan karena pertumbuhan jumlah penduduk dari tahun ke tahun tidak diimbangi dengan penanganan sampah yang memadai. Masyarakat terutama masyarakat desa kurang mendapat informasi dan pengetahuan mengenai penanganan limbah, baik itu limbah padat, limbah cair, dan limbah padat. Sehingga pada kesempatan ini dilakukan kegiatan pengabdian masyarakat di Desa Bengkel lokasi yang masyarakatnya belum dapat menangani sampah dengan baik terutama sampah organik. Selama ini sampah organik hanya dibakar. Kegiatan pengabdian ini bertujuan agar masyarakat lebih memahami dan dapat langsung mempraktekkan cara penanganan sampah organik sehingga dapat meningkatkan nilai tambah sekaligus mengurangi jumlah sampah dengan mengkonversi ke bentuk energi yang dapat dimanfaatkan.

Kegiatan penyuluhan ini dilaksanakan di salah satu dusun, yaitu Dusun Merembu dengan pertimbangan bahwa di desa ini dihasilkan limbah biomassa yang cukup banyak, sehingga diperlukan teknologi penanganan limbah yang tepat untuk mengubahnya menjadi briket dengan nilai ekonomi tinggi. Selain itu, desa ini memiliki masyarakat yang mampu membaca peluang usaha dan memiliki motivasi untuk menjadi lebih baik dari sisi ekonomi. 


\section{METODE}

Kegiatan ini dilakukan dengan metode sosialisasi, diskusi, dan praktek langsung di lapangan. Evalusi kegiatan ini dilakukan melalui dua tahap. Pada tahap pertama, dilakukan penyebaran kuisioner berisi butir-butir pertanyaan yang berkaitan tentang materi pelatihan. Hal ini bertujuan untuk menilai kesiapan dan minat masyarakat terhadap materi yang akan diberikan. Pada tahap kedua, dilakukan evaluasi setelah penyampaian materi dan praktek. Evaluasi dilakukan dengan melihat tanggapan peserta dan kemampuan penguasaan materi yang telah diberikan. Tanggapan dan penguasaan materi diukur dengan memantau pertanyaan yang disampaikan peserta kepada penyaji materi, keaktifan peserta saat melakukan praktek dan kehadiran peserta.

\section{HASIL DAN PEMBAHASAN}

Kegiatan pengabdian ini dilaksanakan pada tanggal 12 Februari 2019 bertempat di Dusun Merembu Barat Mekar, Desa Bengkel, Kecamatan Labuapi dengan peserta masyarakat petani khususnya petani budidaya jamur. Dusun Merembu Barat Mekar merupakan daerah dengan mayoritas penduduknya sebagai petani. Kondisi topografi di daerah ini termasuk dataran rendah dengan banyak pepohonan dan sawah. Jumlah penduduknya tergolong banyak, menurut data BPS jumlah penduduk Dusun Merembu 2402 jiwa. Permasalahan yang dihadapi penduduk Desa Merembu adalah semakin bertambahnya sampah yang berasal dari limbah biomassa. Biomassa adalah bahan organik yang dihasilkan melalui pross fotosintetik, baik berupa produk maupun buangan. Contoh biomassa antara lain adalah tanaman, pepohonan, rumput, ubi, limbah pertanian, limbah hutan, tinja dan kotoran ternak. Dari hasil survey lapangan, di Dusun Merembu banyak terdapat limbah biomassa yang berasal dari hasil panen padi (sekam), sampah daun, dan sampah dari baglog jamur.

Selama ini sampah yang dihasilkan hanya dibuang atau dibakar begitu saja. Hal ini tentunya tidak memberikan manfaat bagi masyarakat. Selain itu, proses pembakaran akan menimbulkan polusi udara dan merugikan bagi kesehatan. Terdapat banyak hal yang dapat dilakukan dalam upaya memanfaatkan limbah organik menjadi produk yang bernilai ekonomis, misalnya dengan mengolah bahan organik menjadi pupuk kompos dalam bentuk pupuk cair atau padat, selain itu pemanfaatan limbah biomassa dapat dikonversikan menjadi bentuk energi lain, seperti biobriket yang dihasilkan dari proses gasifikasi.

Proses gasifikasi adalah proses konversi energi secara termokimia dimana terjadi penguraian biomassa yang dilakukan di dalam suatu alat yang disebut reaktor gasifier. Penguraian tersebut dilakukan dengan cara pemanasan dengan suhu sekitar $900^{\circ} \mathrm{C}$ (Suyitno, 2008). Bahan baku yang biasanya digunakan dalam proses gasifikasi adalah limbah pertanian dan kayu. Adapun jenis gas yang digunakan pada proses gasifikasi, yaitu $\mathrm{CO}, \mathrm{H}_{2}, \mathrm{CH}_{2}, \mathrm{~N}_{2}$, dan $\mathrm{CO}_{2}$. Rezaiyan \& Cheremisinoff (2005) menyebutkan beberapa keunggulan dari teknologi gasifikasi, yaitu:

1. Mampu menghasilkan produk gas yang konsisten yang dapat digunakan sebagai pembangkit listrik

2. Mampu memproses beragam input bahan bakar termasuk batu bara, minyak mentah berat (heavy crude oil), biomassa, berbagai macam sampah kota (municipal waste), dan lain sebagainya

3. Mampu mengubah sampah yang bernilai rendah menjadi produk yang bernilai lebih tinggi

4. Mampu mengurangi jumlah sampah padat

5. Gas yang dihasilkan tidak mengandung furan dan dioksin yang berbahaya

Dalam reaktor gasifier, terjadi beberapa proses seperti: pengeringan, pengarangan, oksidasi dan reduksi hingga dihasilkan gas yang sesuai dengan spesifikasi (Gambar 1). Untuk lebih jelasnya berikut ulasan mengenai masing-masing proses tersebut:

1. Proses pengeringan/penguapan

Pengeringan merupakan tahap awal pada proses gasifikasi ini, dimana kandungan air dalam biomassa diuapkan oleh gas panas dari reaksi oksidasi pembakaran pada bagian bawah reaktor. Temperatur yang digunakan pada proses ini berkisar $170^{\circ} \mathrm{C}$. 
2. Proses Pengarangan (Pirolisa)

Selanjutnya, bahan bakar yang telah kering akan mengalami pemanasan pada temperatur 500$700^{\circ} \mathrm{C}$. Pada proses ini terjadi pembakaran yang tidak sempurna sehingga bahan bakar akan terurai menjadi arang, asam organik, dan juga dalam bentuk zat-zat lain.

3. Proses Oksidasi

Dalam proses gasifikasi akan terjadi juga proses oksidasi, tepatnya setelah tahap pembakaran dan pengarangan selesai. Zat yang dihasilkan dibakar dengan menggunakan bantuan udara, sehingga menghasilkan gas yang mampu terbakar dengan sempurna. Disamping itu akan terbentuk juga gas $\mathrm{CO}_{2}$ yang disertai dengan timbulnya energi panas. Gas yang dihasilkan pada proses ini adalah jenis gas yang dapat ditarik atau dikeluarkan langsung dari dalam reaktor.

4. Proses Reduksi

5. Tahap ini merupakan proses terakhir proses gasifikasi dimana akan terjadi pertukaran uap air serta terjadi reduksi $\mathrm{CO}_{2}$ oleh arang karbon. Akibat dari proses ini, jumlah gas yang dihasilkan akan mengalami peningkatan secara signifikan.

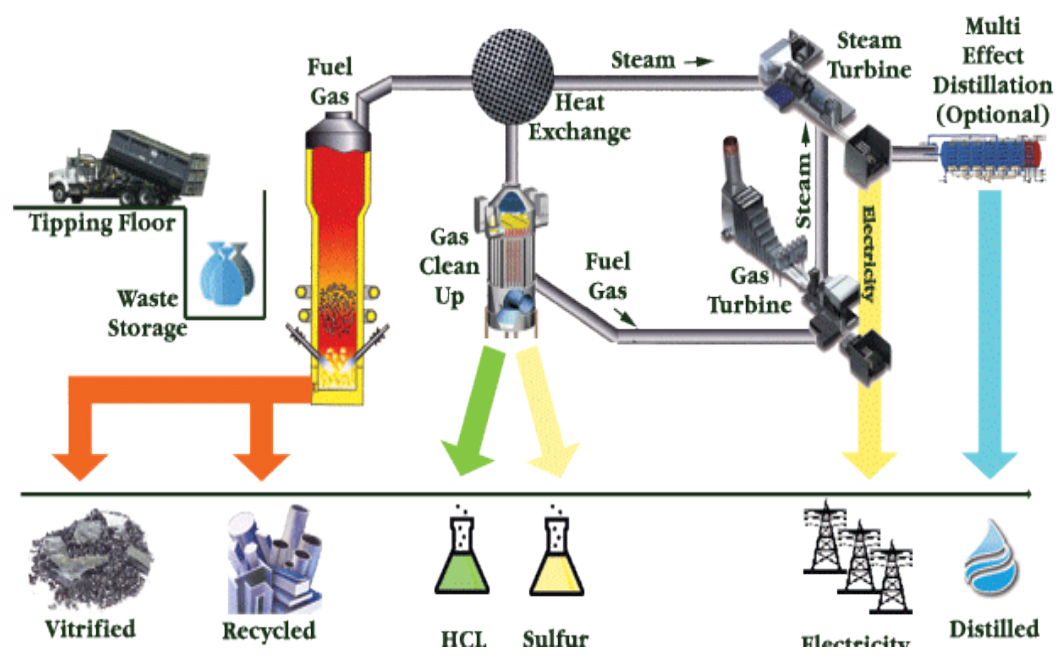

Gambar 1. Proses Gasifikasi Limbah Padat

Selain gasifikasi, penanganan limbah biomassa dapat dilakukan dengan proses pirolisis (Gambar 2). Pirolisis adalah dekomposisi termokimia bahan organik melalui proses pemanasan tanpa atau sedikit oksigen atau pereaksi kimia lainnya (Kramer, et al., 2009). Pada proses ini material mentah akan mengalami pemecahan struktur kimia menjadi fase gas. Pirolisis adalah kasus khusus termolisis. Dalam pirolisis ekstrem, hanya dihasilkan karbon sebagai residu, sehingga proses ini disebut juga karbonisasi. Proses ini digunakan secara umum dalam industri kimia, misalnya, untuk menghasilkan arang, karbon aktif, metanol, dan bahan kimia lainnya dari kayu, untuk mengkonversi etilena diklorida menjadi vinil klorida dalam pembuatan PVC, untuk menghasilkan kokas dari batubara, untuk mengubah biomassa menjadi gas sintesis dan biochar, untuk mengubah limbah plastik kembali menjadi minyak yang dapat digunakan atau limbah menjadi zat yang aman sekali pakai, dan untuk mengubah hidrokarbon dengan berat molekul menengah (contoh: minyak) menjadi yang lebih ringan (contoh: bensin). Pirolisis juga digunakan dalam pembuatan nanopartikel, zirkonia dan oksida (Pingali, et al., 2005) memanfaatkan nozzle ultrasonik dalam proses yang disebut ultrasonic spray pyrolysis (USP). 


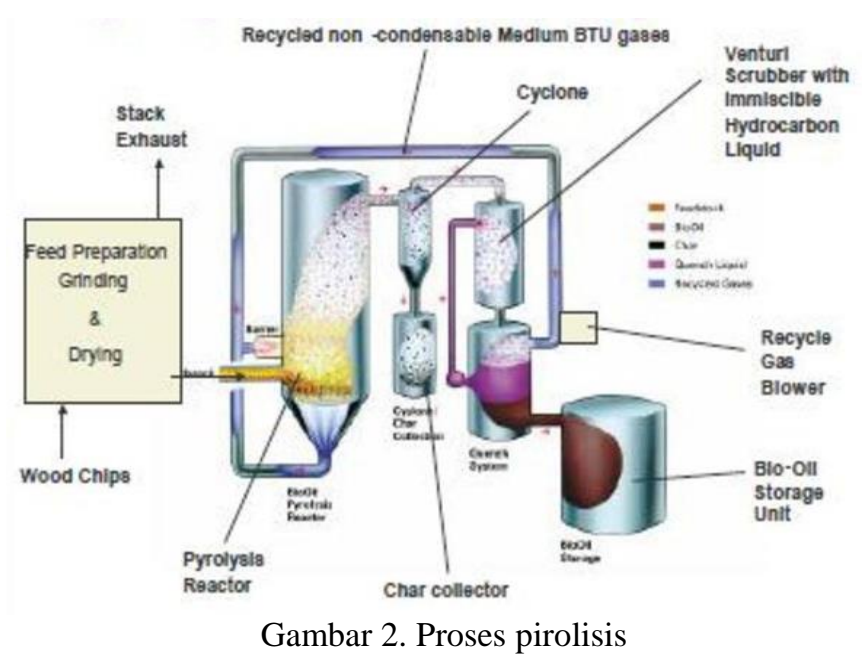

Selain kedua proses tersebut, penanganan limbah biomassa dapat dilakukan dengan proses likuifaksi (liquification). Liquification merupakan proses perubahan wujud dari gas ke cairan dengan proses kondensasi (biasanya melalui pendinginan), dengan peleburan (perubahan dari padat ke cairan), dengan pemanasan atau penggilingan, dan pencampuran dengan cairan lain untuk memutuskan ikatan. Pada bidang energi, liquifaction dilakukan untuk merubah batubara dan gas menjadi bentuk cairan dengan tujuan menghemat biaya transportasi dan memudahkan pemanfaatan (Anonim, 2008).

Adapun penanganan limbah biomassa yang disosialisasikan pada kegiatan pengabdian ini adalah teknologi sederhana untuk mengkonversi limbah biomassa atau limbah organik menjadi briket. Briket adalah biomassa yang dimampatkan sehingga bentuknya menjadi lebih teratur yang kemudian dapat dimanfaatkan menjadi sumber energi terbarukan (Tambunan, dkk., 2008). Briket yang terkenal adalah briket batubara. Namun, tidak hanya batubara saja yang dapat diubah menjadi briket. Biomassa lain seperti sekam, arang sekam, serbuk gergaji, serbuk kayu, dan limbah lain dapat dibuat menjadi briket. Pembuatan briket cukup mudah dilakukan, alat yang digunakan juga sederhana.

Briket dibuat dengan menekan dan mengeringkan campuran bahan menjadi blok yang keras. Metode ini umum digunakan untuk batu bara yang memiliki nilai kalori rendah atau serpihan batu bara agar memiliki tambahan nilai jual dan manfaat. Briket digunakan di industri dan rumah tangga. Bahan yang digunakan untuk pembuatan briket sebaiknya yang memiliki kadar air rendah untuk mencapai nilai kalor yang tinggi. Keberadaan bahan volatil juga mempengaruhi seberapa cepat laju pembakaran briket; bahan yang memiliki bahan volatil tinggi akan lebih cepat habis terbakar (Hazra, dkk., 2011).

Dibandingkan pembakaran biomassa secara langsung, pembakaran briket biomassa menghasilkan panas per satuan volume lebih tinggi. Kondisi ini memudahkan transportasi karena briket biomassa dibuat dengan menekan limbah biomassa menjadi bentuk tertentu dan lebih padat (Tambunan, dkk., 2008). Dibandingkan bahan bakar fosil, briket biomassa memiliki total emisi gas rumah kaca yang rendah karena komponennya merupakan bagian dari siklus karbon pendek.

Kegiatan ini diawali dengan diskusi oleh tim penyuluh kepada masyarakat mengenai permasalahan limbah sampah organik (Gambar 3). Saat ini kepedulian masayarakat untuk mengolah sampah masih sangat minim. Sampah biasanya hanya dibuang atau dibakar. Sampah yang dibuang akan memenuhi Tempat Pembuangan Akhir (TPA) dan semakin lama akan menjadi masalah serius jika tidak segera ditangani dengan benar. 


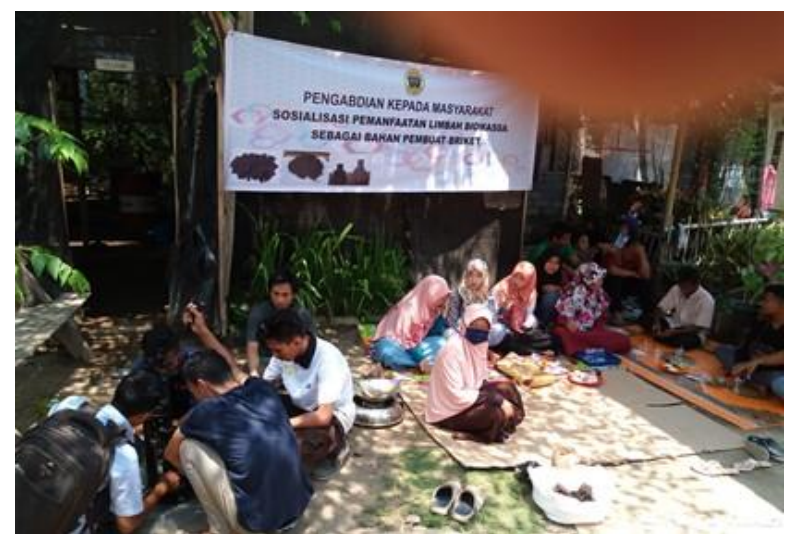

Gambar 3. Diskusi proses pengolahan limbah organik menjadi briket

Oleh karena itu, pelatihan pengolahan sampah organik dilakukan untuk menambah wawasan dan pengetahuan bagi masyarakat agar sampah dapat dikelola menjadi produk yang bermanfaat. Di Desa Merembu keberadaan sampah organik sangat berlimpah. Sampah organik tersebut berasal dari sekam padi, pohon kayu, kertas, ranting, dan daun kering. Baglog jamur adalah jenis limbah padat yang juga cukup banyak dihasilkan di Dusun Merembu, terutama oleh petani budidaya jamur. Selama ini keberadaan sampah tersebut cukup meresahkan karena semakin banyak timbunan sampah yang berserakan di sekitar tempat tinggal dan saat dibakar menimbulkan polusi udara yang mengganggu kesehatan warga sekitar.

Teknologi yang diperkenalkan oleh tim penyuluh adalah pemanfaatan limbah organik untuk dikonversi menjadi briket. Metode ini dipilih karena dianggap paling mudah untuk dilakukan dan pemanfaatannya bisa langsung digunakan oleh masyarakat serta proses pembuatannya pun terbilang mudah. Tidak perlu kemampuan khusus untuk membuat briket, mulai dari bapak-bapak, ibu-ibu dan remaja semua dapat membat briket dengan teknologi yang diperkenalkan oleh tim penyuluh. Di wilayah NTB, khususnya di Desa Merembu, istilah briket masih dianggap asing dan menurut hasil survey lapangan banyak warga yang belum mengenal briket.

Proses pembuatan briket diawali dengan persiapan alat dan bahan. Alat-alat yang digunakan cukup sederhana terdiri dari: ayakan dengan lubang kecil, tempung kanji, satu set kompor dan wajan, pengaduk kayu, wadah plastik, paralon atau pipa PVC diamater 2 inchi, palu, dan gergaji. Bahan yang diperlukan untuk membuat briket adalah limbah biomassa (sekam), air, dan tepung kanji. Bahan yang sudah disiapkan kemudian diproses ke tahap selanjutnya mengikuti diagram alir pada Gambar 4.

\section{Proses Pembuatan Briket}

\section{Pengarangan}

Bahan baku (limbah biomassa) dibuat arang dengan cara pengarangan manual menggunakan tong. Bahan dalam tong kemudian dibakar lalu tong ditutup hingga hanya ada sedikit ventilasi pada tong pengarangan tersebut. Pengarangan juga dapat dilakukan dengan proses pirolisis, dimana limbah biomassa dimasukkan ke dalam tangki pirolisis dalam keadaan tertutup, kemudian asap dikondensasikan hingga menjadi asap cair. Pada gambar 5, diperlihatkan teknologi pepirolisis sederhana bantuan tungku kawat yang dibentuk seperti silinder dan diposisikan berdiri pada tengah-tengah tumpukan sekam. Di dalam silinder kawat dimasukkan daun kering yang kemudian dibakar, panas yang dihasilkan dari proses pembakaran di dalam silinder akan menyebabkan sekam di sekeliling silinder menghitam. Sekam yang menghitam seluruhnya menunjukkan proses pirolisis telah selesai dan sekam berubah menjadi arang. 


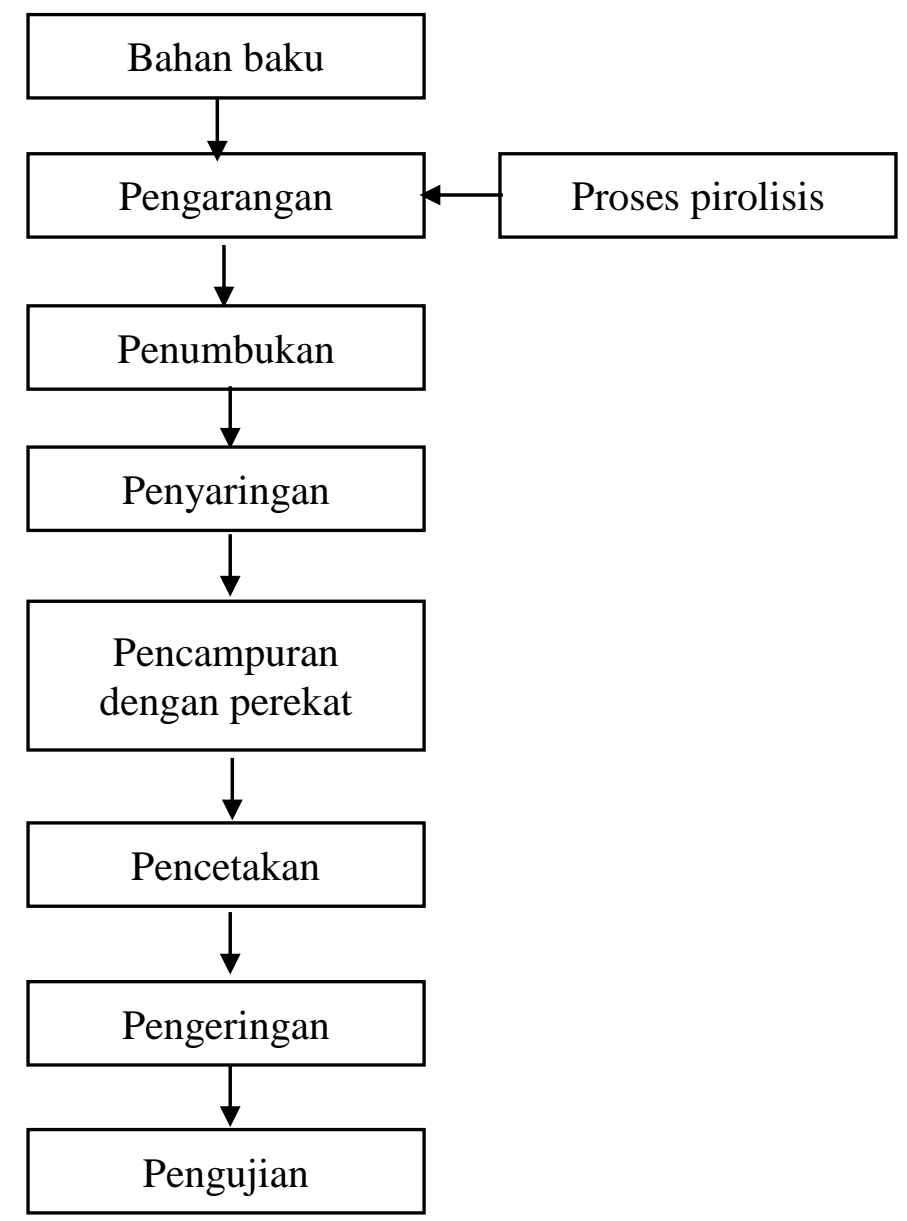

Gambar 4. Proses pembuatan briket
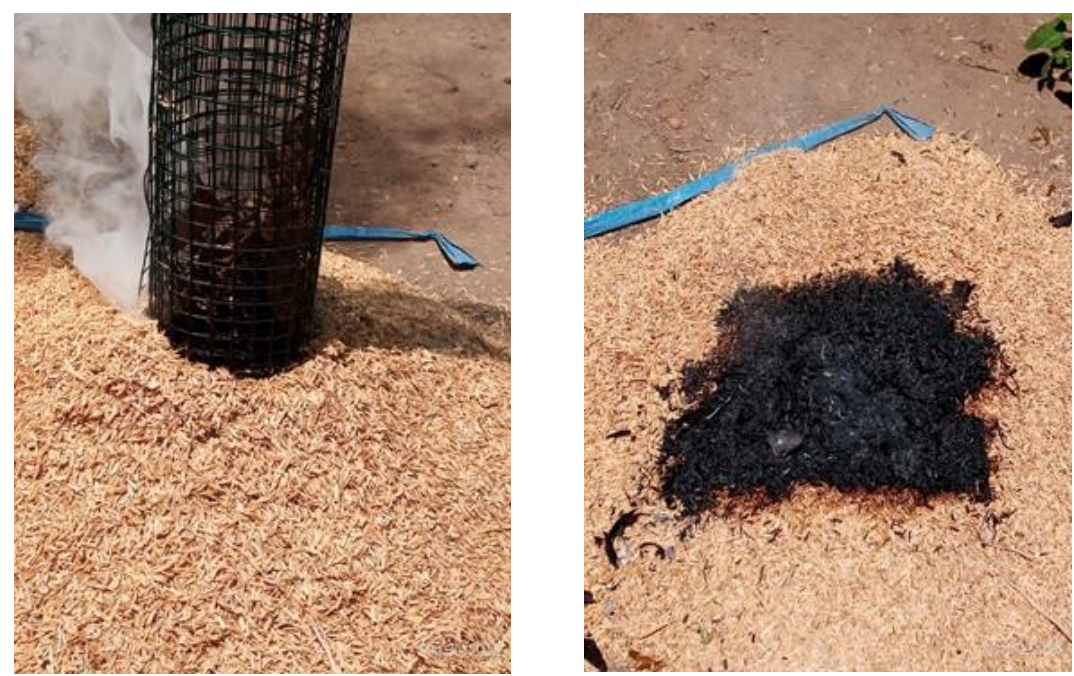

Gambar 5. Proses Pirolisis sekam padi 


\section{Penumbukan}

Arang yang dihasilkan melalui pembakaran manual atau pirolisis kemudian dibuat menjadi tepung dengan cara ditumbuk manual menggunakan palu.

\section{Pencampuran media}

Hasil arang yang telah disaring selanjutnya dicampur dengan lem kanji sebanyak 2,5\% dari arang.

\section{Pencetakan Briket Arang}

Setelah bahan-bahan tersebut dicampur secara merata selanjutnya dimasukkan ke dalam cetakan briket dan kemudian dilakukan penjemuran.

\section{Hasil evaluasi}

Kegiatan ini berguna untuk melihat respon masyarakat terhadap pemanfaatan limbah organik sebagai bahan pembuatan briket. Setelah masyarakat memahami akan pentingnya pengolahan limbah, banyak peserta antusias untuk mempelajari lebih jauh cara pembuatan briket, karena dirasa mudah dan sangat bermanfaat. Briket ini dapat dimanfaatkan sebagai sumber pemanas alternatif untuk berbagai kegiatan, salah satunya adalah untuk bahan bakar pengolahan jamur menjadi keripik jamur.

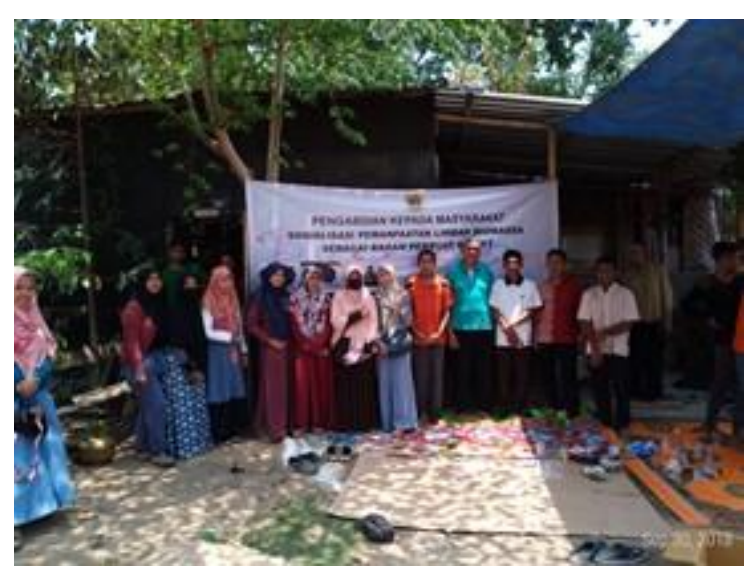

Gambar 6. Foto bersama masyarakat desa Merembu

\section{KESIMPULAN DAN SARAN}

Kegiatan sosialisasi berjalan dengan lancar dan masyarakat memahami proses pengolahan limbah organik (berupa sekam padi, ranting pohon, limbah baglog jamu dan daun kering) menjadi briket yang dapat memberikan nilai lebih dan manfaat bagi masyarakat setempat. Untuk kegiatan pengabdian selanjutnya disarankan untuk melakukan sosialisasi alternatif teknologi lain dalam penanganan limbah organik selain dikonversi menjadi briket.

\section{DAFTAR PUSTAKA}

Anonim. 2008. Energi Listrik Pertanian. IPB: Bogor.

Dinas Lingkungan Hidup Kota Mataram. 2018. Kota Mataram Dalam Data. 
Hazra, F., dan Sari, N. 2011. Biomassa tempurung buah nyamplung (Callophyllum spp) untuk pembuatan briket arang sebagai bahan bakar alternatif. Jurnal Sains Terapan. 3: 34-39.

Kramer, C. A., Loloee, R., Wichman, I. S., and Ghosh, R. N. 2009. Time Resolved Measurements of Pyrolysis Products From Thermoplastic Poly-Methyl-Methacrylate (PMMA). Proceedings of the ASME 2009 International Mechanical Engineering Congress \& Exposition. Florida, November 13-19.

Pingali, K.C., Rockstraw, D. A., and Deng, S. 2005. Silver Nanoparticles from Ultrasonic Spray Pyrolysis of Aqueous Silver Nitrate (PDF). Aerosol Science and Technology. 39 (10): 10101014. doi:10.1080/02786820500380255.

Rezaiyan, J., and Cheremisinoff, N. P. 2005. Gasification Technologies: A Primer for Engineers and Scientists. Taylor \& Francis Group LCC: USA.

Suyitno, Techn. 2008. Teknologi Gasifikasi Biomasa untuk Penyediaan Listrik dan Panas Skala Kecil Menengah; Dalam Kumpulan Potret Hasil Karya IPTEK. UNS Press: Surakarta.

Tambunan, A., Mandang, T., Hambali, E., Agustina, S. E., Salundik, Nugroho, N., Irzaman, Setyaningsih, D. 2008. Agenda riset energi Institut Pertanian Bogor 2008-2012. Research Agenda of IPB. 